10）柴崎武義·大島英紀：日本鉱業会秋季大会，福岡，昭和 52 年

11) M. Goto \& K. Kanamori : The 108 th AIME Annual Meeting, New Orleans, Louisiana, Feb. 1979

12) T. Suzuki \& M. Goto : The Annual Meeting of Arizona Section, The Metallurgical Society of AIME,Tucson, Arizona, Dec. 3rd, 1979

13) M. Goto \& T. Echigoya : The 109 th AIME Annual Meeting, Las Vegas, Nevada, Feb. 1980
14）市田則光：日本鉱業会誌，87〔1001〕，509－514，（1971〕

15) H. Uchida, N. Kikumoto \& M. Hayashi : U. S E.P.A. Symposium, Montery, California, March, 1979

16) K. Itakura, T. Nagano \& J. Sasakura : The 99 th AIME Annual Meeting, Feb. 1969

17) T. Suzuki, H. Uchida \& H. Mochida: The 106 th AIME Annual Meeting, Atlanta, Georgia, March, 1977

Copper Smelting and Refining at Naoshima Smelter

by Motoo GOTO

The Naoshima Smelter is located on the Naoshima Island, which lies in the Seto Inland Sea, Japan, about 200 kilometers west of Osaka.

The Naoshima Smelter was built in 1917 to treat domestic copper concentrates with a reverberatory furnace. Since then, the smelter has gradually expanded its production capacity. The major expansion project was completed in 1969 adding a new smelter and a tankhouse with a capacity of 7,500 tons copper cathode per month. The old smelter was then scrapped at the end of 1973 after 56 years of operation and the entirely new Mitsubishi Continuous Copper Smelting Process has taken its place with a monthly capacity of 4,000 tons anode from concentrates, while the tankhouse was expanded at the same time.

In total, there are two smelter lines and tankhouse buildings with following production capacities.

Copper conc. treated $\quad 45,000 \mathrm{M} . \mathrm{t} / \mathrm{month}$

continuous smelter line $\quad 17,500$

conventional smelter line $\quad 27,500$

Electrolytic copper

41,000

Sulfuric ac

Sulfuric acid
The conventional smelter is composed of a fluo-solid roaster, calcine charged reverberatory furnace, three P.S converters, and two anode furnaces. The continuous process is carried out with a smelting furnace, a slag cleaning furnace and a converting furnace which are mutually linked with launders to allow continuous transfer of intermediate metallurgical products. The Naoshima Smelter is expected to develop further in the future with making the most use of this Mitsubishi Process.

\title{
〔1-11〕 新居浜工場における銅製錬および副産物の製造
}

今 澤 博 $^{1}$

1. 緒

言

新居浜工場は, 昭和 54 年 5 月で創業 60 周年を迎えた。最近の約 10 年間は, 40 年代前半の高度経済成長, 続く 40 年代後半の $=ク y$ ンショック, オイルショックならびに公害諸問題の顕在化等, 内

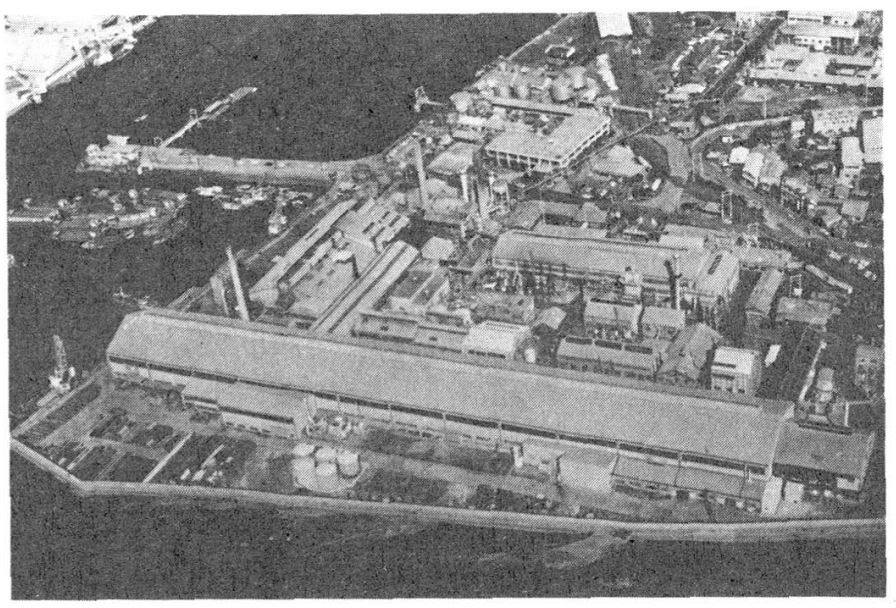

第 1 図 住友別子事業所の精銅工場全景

* 正会員 住友金属鉱山株式会社別子事業所精銅工場長
外情勢の変化においてまさに激動の時代であつたといえる。当工 場においては昭和 44 年 2 月に産銅月産 1 万 t 体制が確立され，そ れに呼応して殿物処理についても新分銀工場を建設した。その後, 46 年には東予製鍊所が建設され精製アノードの約50〜70\%を同製 鍊所から供給されることになり，これに伴い四阪粗銅の受入は昭 和51年10月で中止した。また銅殿物については昭和48年の 東予製鍊所銅電解工場の稼動開始に伴い，同工場産銅殿物 も当工場で合わせて処理することとなつた。

昭和51年まで当工場の電気銅生産は, ほぼフル稼動で推 移したものの, 最近では月産約 8 千 $\mathrm{t}$ で推移している。こ の低成長下にあつて, 一方では省力化, 省エネルギーおよ び停滞金利の圧縮などの対策に積極的に取組んできた。

以下に, これまでの約 10 年間の新居浜工場における変遷 と現在の概要を述べる。

\section{2. 操 業 概 要}

新居浜工場は，銅電解と銅殷物処理を主力とし，電気銅， 電気金, 電気銀等を産出している。原料としては, 東予製 鍊所産精製了, ードの他に外国粗銅, 故銅類, 鉛電解スラ イムなどが主体である。

\section{$2 \cdot 1$ 生産量および分析值}

昭和 43 年以降の製品別生産量の推移を第 1 表, 昭和 54 年

$658<58>$ 
第1表 生産量の推移（昭和 $43 \sim 54$ 年度）

\begin{tabular}{|c|c|c|c|c|c|c|c|c|c|c|}
\hline 年度別 & 電 気 金 & 電 気 銀 & 電 気 銅 & 硫 酸 銅 & セレン & テル ル & 金 & パラジウム & ロジウム & 酸 化 銀 \\
\hline 昭和 & $\begin{array}{r}\mathrm{kg} \\
5.736\end{array}$ & $\begin{array}{r}\mathrm{kg} \\
86.496\end{array}$ & $90-{ }^{t}$ & ${ }^{t}$ & $\begin{array}{r}\mathrm{kg} \\
378\end{array}$ & $\mathrm{~kg}$ & $\mathrm{~kg}$ & $\mathrm{~kg}$ & $\mathrm{~kg}$ & $\mathrm{~kg}$ \\
\hline 44 & 7,164 & 112,272 & $\begin{array}{r}90,390 \\
104,130\end{array}$ & $\begin{array}{l}3,562 \\
4,098\end{array}$ & $\begin{array}{l}27,328 \\
46,818\end{array}$ & - & $\begin{array}{l}\text { 15. } 1 \\
\text { 21. } 2\end{array}$ & $\begin{array}{l}\text { 51. } 4 \\
34.2\end{array}$ & - & $\overline{-}$ \\
\hline 45 & 6,564 & 109,428 & 99,597 & 3,745 & 42,390 & - & 24. 5 & 63. 0 & - & - \\
\hline 46 & 5,862 & 97,620 & 107,389 & 3,732 & 51,085 & - & 70.0 & 117. 6 & - & - \\
\hline 47 & 7, 031 & 92,616 & 115,897 & 3,797 & 71,872 & - & 32. 6 & 75. 3 & - & - \\
\hline 48 & 6,348 & 76,224 & 105,508 & 4,225 & 55,150 & - & 92.1 & 227.7 & - & - \\
\hline 49 & 6,180 & 71,160 & 108,717 & 3,747 & 46,953 & - & 89.8 & 279. 2 & - & - \\
\hline 50 & 4,812 & 71,172 & 119,360 & 2,421 & 47,861 & - & 109. 0 & 310.5 & - & - \\
\hline 51 & 5,160 & 81,144 & 113,649 & 2,376 & 48,045 & 4,242 & 128. 0 & 351.0 & 3. 7 & - \\
\hline 52 & 6,348 & 91,092 & 93,773 & 3,753 & 53,423 & 12,200 & 145. 5 & 555. 0 & 4. 0 & - \\
\hline 53 & 4,512 & 110,252 & 96,215 & 3,695 & 66,398 & 11,543 & 172. 2 & 462. 6 & 9. 2 & 1,050 \\
\hline 54 & 4,452 & 112,500 & 100,080 & 3,864 & 62,880 & 5,046 & 240.0 & 530.2 & 13. 1 & 1,680 \\
\hline
\end{tabular}

第 2 表 原料, 製品の分析値 (昭和 54 年度平均)

\begin{tabular}{|c|c|c|c|c|c|c|c|c|c|c|c|c|c|c|}
\hline & $\mathrm{Au}$ & $\mathrm{Ag}$ & $\mathrm{Cu}$ & $\mathrm{Pb}$ & $\mathrm{Fe}$ & $\mathrm{S}$ & As & $\mathrm{Sb}$ & $\mathrm{Bi}$ & $\mathrm{Sn}$ & $\mathrm{Ni}$ & $\mathrm{Se}$ & $\mathrm{Te}$ & $\mathrm{O}_{2}$ \\
\hline 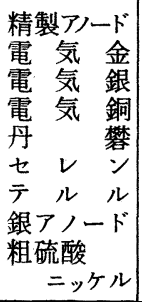 & $\begin{array}{c}22.3 \mathrm{~g} / \mathrm{t} \\
99.99 \% \\
- \\
<0.1 \mathrm{~g} / \mathrm{t} \\
- \\
- \\
- \\
3.70 \%\end{array}$ & $\begin{array}{c}586 \mathrm{~g} / \mathrm{t} \\
4 " \\
99.99 \% \\
7.0 \mathrm{~g} / \mathrm{t} \\
- \\
- \\
- \\
94.20 \% \\
-\end{array}$ & $\left|\begin{array}{c}99.2 \% \\
- \\
0.0001^{\prime \prime} \\
99.99 " \\
25.34 " \\
- \\
- \\
0.59 \prime \\
-\end{array}\right|$ & $\begin{array}{r}0.07 \% \\
- \\
<0.0001 " \\
<0.0001 " \\
- \\
- \\
0.55 \\
-\end{array}$ & $\mid \begin{array}{rr}0.004 & \% \\
- & - \\
0.0001 " & 0.001 " \\
0.01 & \prime \prime \\
- & - \\
- & -\end{array}$ & $\begin{array}{c}0.005 \% \\
- \\
- \\
0.0008 " \\
- \\
- \\
- \\
- \\
-\end{array}$ & $\begin{array}{r}0.084 \% \\
- \\
- \\
<0.0001 " \\
- \\
- \\
- \\
-\end{array}$ & $\begin{array}{r}0.024 \% \\
- \\
- \\
<0.0001 " \\
- \\
- \\
- \\
- \\
-\end{array}$ & $\begin{array}{r}0.011 \% \\
- \\
<0.0001 " \\
<0.0001 " \\
- \\
- \\
0.12 \\
-\end{array}$ & $\begin{array}{r}0.002 \% \\
- \\
- \\
<0.0001 " \\
- \\
- \\
- \\
-\end{array}$ & $\begin{array}{r}0.132 \% \\
- \\
- \\
<0.0001 " \\
0.04 \quad \\
- \\
- \\
24.5\end{array}$ & $\begin{array}{r}0.038 \% \\
- \\
- \\
<0.0001 " \\
- \\
>99.995 " \\
- \\
- \\
-\end{array}$ & $\begin{array}{r}0.016 \% \\
- \\
- \\
- \\
- \\
- \\
99.99 " \\
- \\
-\end{array}$ & $\begin{array}{c}0.25 \% \\
= \\
= \\
- \\
= \\
= \\
-\end{array}$ \\
\hline
\end{tabular}

第3表 主要設備諸 元

\begin{tabular}{|c|c|c|c|c|c|c|c|}
\hline 工 程 & 設 備 名 & 仕 & 基数 & 工 程 & 設 備 名 & 仕 & 基数 \\
\hline \multirow[t]{5}{*}{ 粗銅精製 } & \multirow[t]{2}{*}{ 精製反射炉 } & \multirow{2}{*}{ 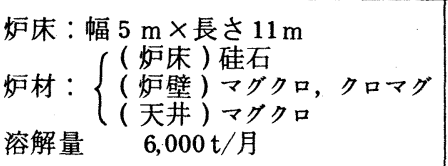 } & \multirow[t]{2}{*}{3 基 } & \multirow[t]{4}{*}{ 銅 浄 液 } & 脱銅電解槽 & $\begin{array}{c}\text { 構造：コンクリート, FRPライニング } \\
\text { 12段カスケード式 }\end{array}$ & 24 槽 \\
\hline & & & & & $\begin{array}{l}\text { サイリスター } \\
\text { 整流器 }\end{array}$ & $\begin{array}{l}\text { 型式：SCR } \\
\text { 量：60V×12,000 A }\end{array}$ & 1 基 \\
\hline & 鋳 造 機 & 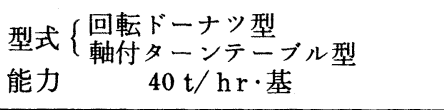 & 2 基 & & 蒸気蒸発槽 & $\begin{array}{c}\text { 構造：コンクリート，鉛板 } \\
\text { 耐酸タイル内張 }\end{array}$ & 2 槽 \\
\hline & \multirow[t]{2}{*}{ 余熱ボイラ } & \multirow{2}{*}{ 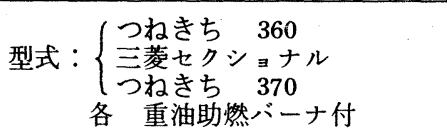 } & \multirow[t]{2}{*}{3 基 } & & 電気蒸発槽 & $\begin{array}{l}\text { 構造：鉄板, 鉛板 } \\
\text { アスベスト, 抗火石 内張 }\end{array}$ & 1 槽 \\
\hline & & & & \multirow[t]{6}{*}{ 殿物処理 } & シックナ & & 1 基 \\
\hline \multirow{4}{*}{ 銅 電 解 } & \multirow{2}{*}{ 電 解 槽 } & \multirow{2}{*}{$\begin{array}{l}\text { 構造 : コンクリート, 鉛・塩ビライ } \\
\text { ニング }\end{array}$} & \multirow{2}{*}{906 槽 } & & 硫酸化 炉 & 型式：パグミル式（間接加熱） & 2 基 \\
\hline & & & & & 焙 焼 炬 & 型式：ロータリーキルン（外熱式 ) & 3 基 \\
\hline & \multirow{2}{*}{$\begin{array}{l}\text { シリュン } \\
\text { 整流器 }\end{array}$} & \multirow{2}{*}{$\begin{aligned} \text { 型式 : } & \mathrm{SiR} \\
\text { 容量 } & :\left\{\begin{array}{c}220 \mathrm{~V} / 440 \mathrm{~V} \\
\times 12,000 \mathrm{~A} / 6,000 \mathrm{~A} \\
220 \mathrm{~V} \times 6,000 \mathrm{~A}\end{array}\right.\end{aligned}$} & \multirow[t]{2}{*}{4 基 } & & 溶 殿 炉 & 型式：電気炉 & 1 基 \\
\hline & & & & & 揮 発 炉 & 型式：転炉（ロッキング式） & 2 基 \\
\hline \multirow{4}{*}{ 丹礬製造 } & \multirow{2}{*}{ 真空蒸発缶 } & \multirow{2}{*}{$\begin{array}{l}\text { 型式 : 二重効用型 } \\
\text { 構造 : 鉄, 鉛ホデン・ゴムライニング }\end{array}$} & \multirow{2}{*}{4 缶 } & & 分 銀 炉 & 型式：反射炉 & 1 基 \\
\hline & & & & 銀 電 解 & 電 解 槽 & 型式：メービアス, 連続式 & 21 槽 \\
\hline & 急冷結晶槽 & 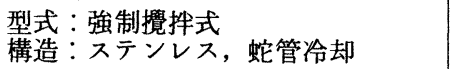 & 6 槽 & 金電解 & 電 解 槽 & 型式：ウォールウィル式 & 8 槽 \\
\hline & 流動乾燥機 & 型式：熱風流動型 & 1 基 & セレン & $\begin{array}{lll}\text { 澴 } & \text { 解 } & \text { 槽 } \\
\text { 元 } & \text { 槽 }\end{array}$ & & $\begin{array}{l}2 \text { 槽 } \\
4 \text { 槽 }\end{array}$ \\
\hline
\end{tabular}

度の原料・製品の分析値を第 2 表に示す。

\section{$2 \cdot 2$ 操業系統図および主要設備諸元}

現在 (昭和55年 4 月) の新居浜工場の操業系統図と主要設備諸 元をそれぞれ第 2 図と第 3 表に示す。

当工場は，古い歴史をもつ銅製鍊本位の工場であるが，「耳下 削りアノード」ならびに「銅イオン添加による脱銅電解法」など を駆使した銅電解工程，「連続式硫酸化焙焼炬」や「ロッキング 式揮発炉」を有する銅殿物処理工程，「高温還元法」などからな る連続式セレン精製工程等, 改良された最新技術を備えている。

\section{3. 設備の堌強ならびに技術的進歩について}

\section{$3 \cdot 1$ 産銅 1 万t 体制の確立}

（1）精製炉増設 銅増産のため昭和43年に精製炬を 1 基増 設し 3 基とした。併わせて鋳造設備ならびにボイラ各 1 基増設し た。同年 9 月より, 精製炬 2 炉操業を開始し,この体制は46年に 東予製鍊所が稼動するまで続いた。

（2）銅電解槽増設 電気銅生産能力を $5,800 \mathrm{t} /$ 月 から $10,000 \mathrm{t} /$ 月に増強するため, 昭和 $41 \sim 44$ 年の間で約 250 槽の増槽 


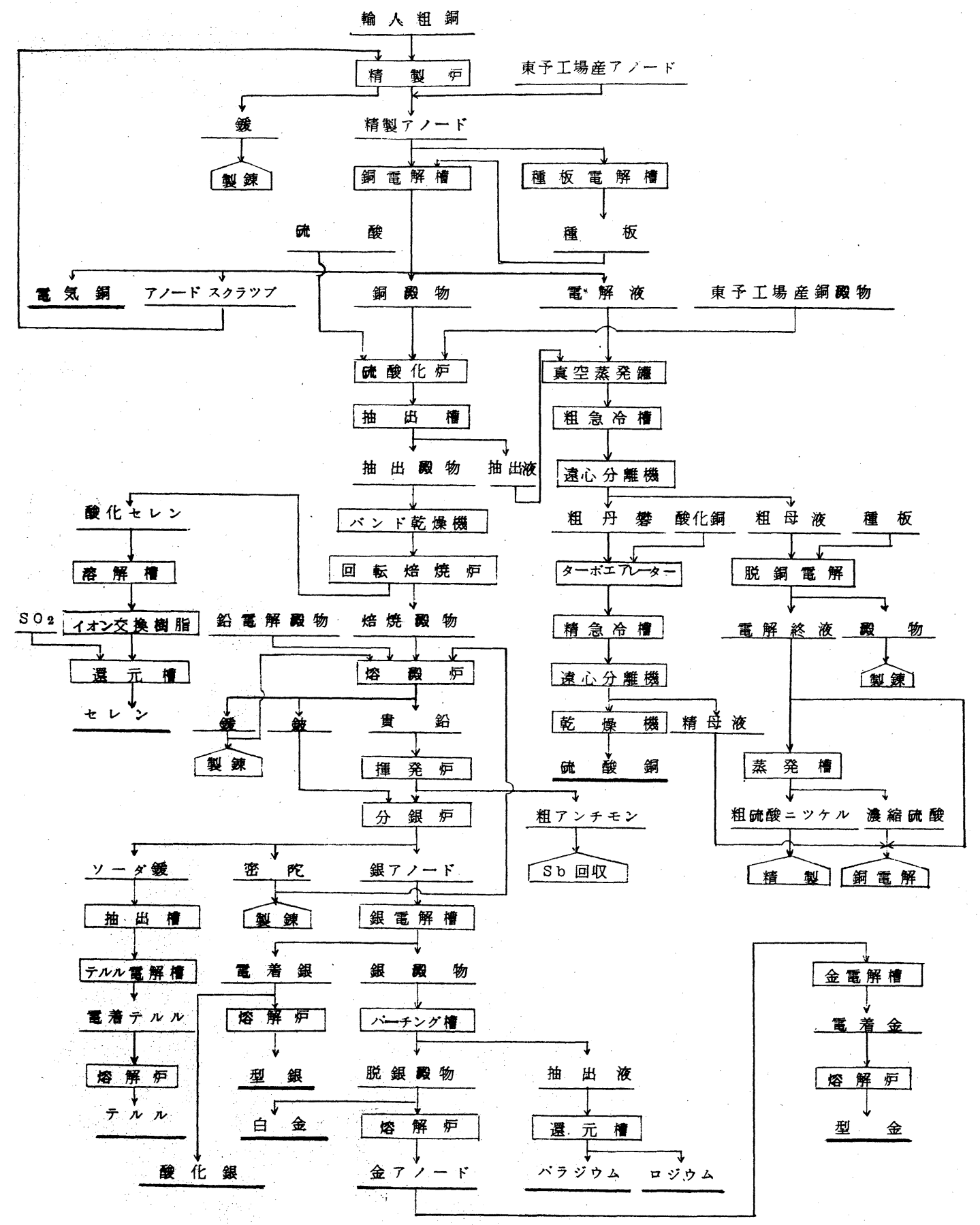

第 2 図操業系統図（昭和 55 年 4 月現在）

を行ない合計 906 槽とした。電解電流については, S i R 整流器を 増設して $17,300 \mathrm{~A}\left(D_{k}=300 \mathrm{~A} / \mathrm{m}^{2}\right)$ まで可能となり，41年12月か ら46年 7 月にかけて $300 \mathrm{~A} / \mathrm{m}^{2}$ 操業を実施した。その後, $D_{k}$ は $210 \sim 260 \mathrm{~A} / \mathrm{m}^{2}$ としている。

（3）新分銀工場建設電気銅増産に伴う銅殿物増加に対処 するため，殿物処理方法を大幅に改善した新分銀工場を建設，昭 和 44 年 2 月に完成し, 同年 4 月より本操業を開始した。特に新分 銀工場では, 連続化による仕掛品の圧縮, 省力化ならびに実収率 の向上に重点を置いた。

\section{$3 \cdot 2$ 精製妒操業の改善}

（1）銅退元方法の改善 昭和45年より，従前の還元方法に 代えて新方式の溶銅還元方法 ${ }^{1}{ }^{1}$ を確立した。この方法は, 未燃が スを 2 次燃焼させるもので, その結果として, 還元時においては 保温用燃料が全く不要になつた他, 黒煙の発生の激減や未燃ガス 充満による爆発の危険性がなくなるなど大きな効果が得られた。

（2）集中処理による効率化 精製炬は，昭和46年に東予製 鍊所が稼動開始して以来 1 炉操業となつたが, 昭和54年からは, さらに炉の効率化を狙いとしてフル能力による集中操業と保温休 
第 4 表耳下削りアノードによる操業成績の一例

\begin{tabular}{|c|c|c|c|c|c|c|c|c|c|c|}
\hline & \multicolumn{2}{|c|}{$7 ノ-F$} & \multicolumn{2}{|c|}{ フノードスクランフ } & \multicolumn{2}{|c|}{ 西勿 } & \multirow{2}{*}{ 流奻 } & \multirow{2}{*}{$\begin{array}{r}\text { 侐 } \\
\mathrm{mV} / \mathrm{T}\end{array}$} & \multirow{2}{*}{ 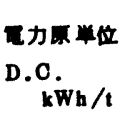 } & \multirow{2}{*}{ 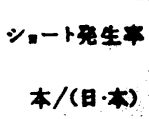 } \\
\hline & 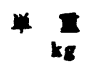 & $0_{k g}$ & $\psi \underset{k g}{K}$ & $0_{\mathrm{kg}}$ & 羍 $\underset{\mathbf{k g}}{\mathbf{E}}$ & $\sigma_{\mathrm{kg}}$ & & & & \\
\hline 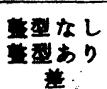 & $\begin{array}{l}339.3 \\
339.3 \\
-\end{array}$ & $\begin{array}{l}1.6 \\
1.6 \\
-\end{array}$ & $\begin{array}{r}60.8 \\
54.9 \\
\Delta 5.9\end{array}$ & $\begin{array}{r}14.5 \\
49 \\
\Delta 9.6\end{array}$ & $\begin{array}{r}142.6 \\
145.5 \\
2.9\end{array}$ & $\begin{array}{r}8.7 \\
5.6 \\
\Delta 3.1\end{array}$ & $\begin{aligned} & 96.0 \\
& 98.0 \\
& 20\end{aligned}$ & $\begin{array}{r}289 \\
284 \\
\Delta 5\end{array}$ & $\begin{array}{r}254 \\
244 \\
\Delta \quad 10\end{array}$ & $\begin{array}{l}10.7 \times 10^{-8} \\
24 \times 10^{-3} \\
8.3 \times 10^{-8}\end{array}$ \\
\hline
\end{tabular}

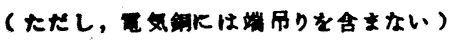

第 5 表 粗丹礬製造工程操業成績の一例

\begin{tabular}{l|c|c}
\hline & 改 善 前 & 改 善 後 \\
\hline 丹礬回収率 & $60 \sim 70 \%$ & $>80 \%$ \\
\hline 粗母液銅濃度 & $25 \sim 35 \mathrm{~g} / l$ & $15 \sim 20 \mathrm{~g} / l$ \\
\hline
\end{tabular}

炬の組合せ操業を行なつている。この操業の確立により, 炉命に 影響もなく大きな省エネ, 省力効果が得られている。

\section{$3 \cdot 3$ 銅電解操業の改善}

(1) 耳下削りアノードの採用従来, アノードには耳下の 鋳張りや板内歪があるため種々の欠点があつた。昭和 48 年, 東予製鍊所に銅電解工場が設置される際, アノードの支持・接点 部の整型装置を開発・導入することになり, 当工場で使用するア ノードも大半が耳下削りアノードに替つた。その結果, アノード の垂直性ならびに電流分布が著しく改善され, 電気銅品質向上, 電力原単位低下など, 操業成績の改善に大きく寄与した。詳細に ついては, 鉱業会誌 ${ }^{2)}$ などに報告されているが, 耳下削りアノー ドによる操業成績の一例を第 4 表に示す。

（2）電解諸原単位の低減化 エネルギー価格の高騰に伴い, 電解電力ならびに電解液加温用蒸気等を削減するため, 昭和 50 年

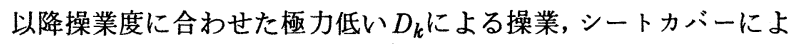
る電槽保温等を実施している。特に, 最近では電解蒸気原単位は 従前の $50 \%$ 以下まで低下してきており, シートカバーの効果はフ ノード不働態化防止なども含め著しいものがある。

\section{$3 \cdot 4$ 丹魔·浄液工程の合理化}

（1）粗丹䙪製造工程の合理化電気銅 1 万 $\mathrm{t}$ 体制確立以来,
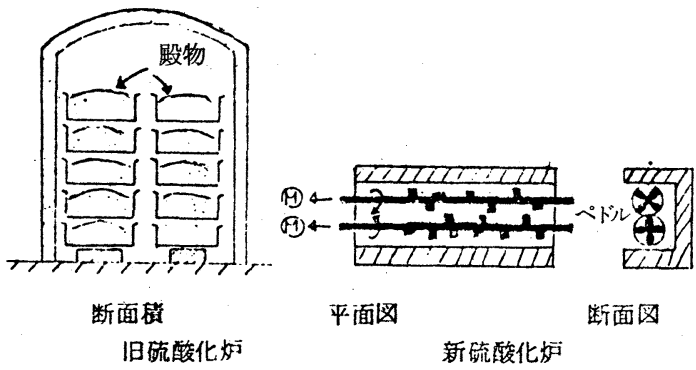

平面図

第3 図 新旧硫酸化炉の比較

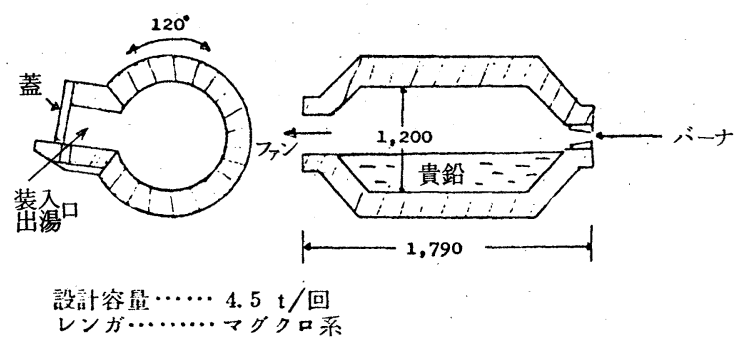

第 4 図 ロッキング炬概略図
第 6表 新旧硫酸化炬の比較 (1)

\begin{tabular}{|c|c|c|}
\hline 項目 方式 & 旧硫酸化妒 & 新硫酸化如 \\
\hline 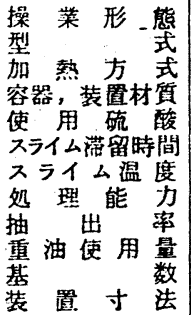 & 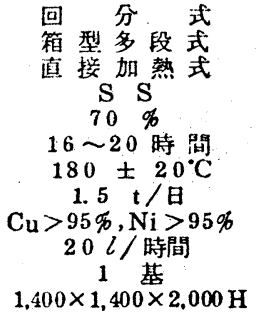 & 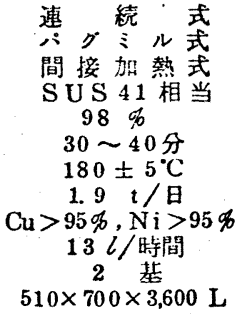 \\
\hline
\end{tabular}

丹攀・浄液工程は順次改善が加えられてきた。特に, 昭和52 53 年には真空蒸発缶等の増設により, 浄液能力は約 1.5 倍となつた が, これに際し凝集剂の活用, ${ }^{3)}$ 結晶分離設備の構造・組合せの改 善などを行なつた。その結果, フローのコンパクト化, 母液組成 の安定化等, 丹礬・浄液工程全体の効率的運転が可能となつた。 第 5 表に操業成績の一例を示す。

（2）脱銅電解工程の改善 昭和53年に脱銅電解設備の更新 等を行なつた。技術的な改善としては, すでに「脱銅電解法 ${ }^{4}$ 〕 等で詳細に発表しているので重複を澼けるが, 昭和46年に連続式 脱銅電解法を確立し, 脱銅量の $20 \sim 40 \%$ を回酸電気銅で回収する とともに, 省エネ, 省力化, 環境対策などを進め, さらに昭和 50 年には銅イオン添加法を開発, この方法により脱銅電解効率を飛 躍的に向上させた。

\section{$3 \cdot 5$ 銅殿物処理工程の改善}

昭和 43 44年にかけて, 分銀ならびにセレンの各新工場が建設 されたが, 新工場の建設・稼動から現在まで多くの技術的改善 ${ }^{5) 6}$ があつた。そのうちの主な事項について列記する。

（1）硫酸化焙焼工程の連続化絮流酸化焙焼炬に代 えて, 間接加熱型パグミル式硫酸化焙焼炬を採用した。この方式 により, 処理能力の向上, 省力化ならびに中間仕掛品の減少を計 ることができた。

第 6 表ならびに第 3 図に新旧硫酸化炉の比較を示す。

(2) 揮発炉によるアンチモンの回収 ${ }^{7)}$ 従来の鉄鍋による方 法では, 脱 $\mathrm{Sb}$ 効率, 涬発生による金銀仕掛り等問題があつたため,

第 7 表 鉄鍋炬とロッキング炉操業成績比較

\begin{tabular}{|c|c|c|c|c|}
\hline & & & 鍋 炉 & ロッキング炉 \\
\hline $\begin{array}{l}\text { 貴 鉛原料脱 } \mathrm{Sb} \text { 貴鉛 } \\
\text { 処 理 時骍 生 } \\
\text { 貴 鉛 }\end{array}$ & $\begin{array}{c}\mathrm{Sb} \\
" \\
\text { 間 } \\
\text { 率 } \\
\text { 率 }\end{array}$ & & $\begin{array}{cc}30.9 & \% \\
16.7 & " \\
118 & \mathrm{hr} \\
18.0 & \% \\
56.1 & "\end{array}$ & $\begin{array}{l}34.6 \% \\
12.9 \% \\
53 \\
4.1 \% \\
63.9 \%\end{array}$ \\
\hline \multirow{3}{*}{$\begin{array}{c}\text { 渀中への } \\
\text { 各成分の } \\
\text { 分配率 } \\
(\%)\end{array}$} & $\mathrm{Ag}$ & & $5.3 \%$ & $0.02 \%$ \\
\hline & $\mathrm{Pb}$ & & 33. $0 "$ & 3. 4 \\
\hline & $\mathrm{Sb}$ & & 18. 1 & 2.0 \\
\hline
\end{tabular}

日本鉱業会誌/971122(’81-8) 661<61> 
新型のロッキング式揮発炬を採用した。その結果, 殿物処理工程 全体の成績が飛躍的に向上したほか, 処理能力の大幅向上, 重油 原単位の減少などの効果が得られた。鉄鍋炬と口ッキング炬の操 業成績の一例を第 7 表, ロッキング炉概略図を第 4 図に示す。

（3）セレン精製方法の改善 ${ }^{8)}$ 昭和 43 年, 亜セレン酸液の高 温還元法を開発し精製工程の自動化を確立した。さらに，セレン 中の水銀除去法の開発により, 水銀をほとんど含まない高純度セ レンの製造ができるようになつた。

$3 \cdot 6$ 連続銀電解法 ${ }^{9)}$ の開発

昭和 45 年, メービアス方式を改善し操業を断続することなく, 連続して操業を行ないうる連続銀電解法 ${ }^{6)}$ を開発した。

$3 \cdot 7$ 新製品の製造

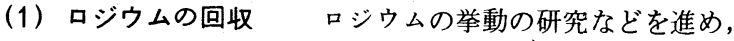
金銀電解工程において効率の良い分離精製法 ${ }^{10}$ を開発した。昭和 50 年より回収を行なつている。

（2）テルルの製造 ${ }^{11 ） ~}$ 分銀炬から産出されるソーダ鍰を原 料として，昭和51年より本格的に製造を行なつている。

（3）酸化銀の製造酸化銀電池用として, 昭和 53 年より生 産を開始した。

\section{4. 省エネルギー事例}

昭和51年10月より, 全社的な省エネ活動が開始された。第 1 次 省エネ活動（昭和51年10月～54年 9 月）では, 新居浜工場の実績 として基準年（50年10月～51年 9 月）に対し $15 \%$ の削減を達成し た。現在, 第 2 次キャンペーンを展開中である。以下に, 今まで の省エネ事例のうち主なものを列挙した。

(1) 銅電解槽シートカバーによる保温 (50年)

電解槽の液面からの放散熱口スを防ぎ, 電解液加温用蒸気の節 減等を計つた。

（2）精製灯熱効率の改善（54年）

フル能力での集中処理および徹底したドラフト管理と燃焼管理 システムの採用により，重油を15\%削減した。

(3) その他

a. 銅浄液フロー改善による電力節減（52年）

b. 分銀炉等銅殿物処理工程の総合的燃焼管理による重油削减 ( $53 \sim 54$ 年)

c. 保温改善による蒸気, 重油の削減 ( 53 年)

d. 圧縮空気の総合的管理によるコンプレッサ等の電力削減 ( 53 年)

\section{5. 環 境 対 策}

新居浜工場は鉱山保安法をはじめ，水質污濁防止法ならびに瀬 戸内海環境保全特別措置法等の適用を受けている。

まず，大気については $\mathrm{SO}_{x}$ の $K$ 值規制（ $K$ 值 $2.34 ）$ ，総量規制に
対し, 重油油種の変更, 脱硫設備の整備等を講じてきた。現状で は, 精製炉には $1 \%$ 硫黄の C 重油を使用し, 殿物処理工程の排力゙ スについては苛性ソーダ吸収法により処理している。 $\mathrm{NO}_{x}$ に関し ては, 相次ぐ規制強化に対しA重油の併用, 燃焼方法の改善等に より対処している。

次に, 水質については昭和 44 年に新しく廃水処理施設を設置す るとともに，極力発生污水の系内繰返しを行ない工場廃水の排出 を最小限としている。

\section{6. 将来への展望と今後の課題}

当面, 銅部門の量的拡大があまり期待されない中にあつては, さらに一層の質的向上を指向していかなければならない。

（1）コストミニマムの追求銅電解については長い伝統に 培われた固有技術と東予新電解工場建設で得られた新技術を生か し, 機械化，省力化を積極的に進める必要がある。同時に, 分銀 工程については複雑鉱の増加に対応しながら，有価金属の完全回 収，徹底した仕掛の圧縮を計らねばならない。

（2）省エネルギー 熱エネルギーの効率的な使い方，代替 エネルギーへの転換ならびに既存工程の見直し等について，大胆 な発想のもとに強力に推進する。

（3）技術開発上記(1)，(2)と相まつて，新技術の開発に積 極的に取組み，さらには銅をはじめとして各種貴金属に到るまで, 既存の製品の付加価值を高めた新製品開発に努めてゆく必要があ る。

以上, 今後に残された課題は大変重要なものばかりであるが, 積極的に取組むことによつて競争力の備わつた活力のある工場を 目ざしたい。

\section{参 考 文 献}

1）堤信夫・佐藤豊 $\cdot$ 田村詔男：特許公報，昭 49-2650

2）今澤博·木下博：日本鉱業会誌，92[1058]，（1976）

3）佐藤浩・石川秀清：特許, 昭 $55-126538$

4）牧野進·佐藤浩：日本鉱業会製鍊関係西日本支部合同研究会謐演資 料, (1977)

5）太田昭夫・清水忠義：日本鉱業会合同秋季大会 ( 秋田) 研究業績発 表講演要旨集, H2-6, (1973)

6）且杵邦夫·木下博·今村伝一：日本鋑業会誌，88[1011], (1972)

7）㷁口伸一・実松成彬：特許, 昭 45-17066

8）下河原達哉・高橋信夫：特許，昭 $49-2650$

9）滝本隆義・石谷至啓：特許, 昭 $49-41241$

10）中野正：日本鈗業会関西・九州支部共催「遺利の回収」に関寸る講 演資料

11）太田昭夫·中野正・高橋光良：特許，昭 $53-35853$

12）下河原達哉·身内茂：特許, 昭 $47-21218$

\section{Copper Refining and Byproducts at Niihama Refinery}

by Hiroshi IMAZAWA

The Niihama Copper Refinery of Sumitomo Metal Mining Co., Ltd., one of the major copper refineries in Japan, is situated in Niihama, one of the leading industrial cities, Shikoku Island, having the Port of Niihama in the back where both coast and ocean going vessels come in and go out through the Seto Inland Sea just outside thereof. The Refinery started operations in 1919 and has been expanded year after year since then. The Refinery produces 10,000 tons per month of electrolytic copper from refined anode, mainly supplied from the Toyo Smelter which is located in the vicinity. The Refinery also produces many by-products such as gold, silver, platinum, selenium, tellurium, bismuth, nickel and rhodium. 